\title{
HUBUNGAN ANTARA KADAR TROPONIN DENGAN KEJADIAN MAJOR ADVERSE CARDIOVASCULAR EVENTS PADA PASIEN SINDROM KORONER AKUT DI RSI JEMURSARI SURABAYA
}

\author{
Elsa Kusumawati, Abraham Ahmad Ali Firdaus, Reza Hery Mahendra Putra \\ Fakultas Kedokteran Universitas Nahdlatul Ulama Surabaya \\ e-mail: els4study@gmail.com
}

\begin{abstract}
Abstrak: Sindroma Koroner Akut (SKA) memiliki variabilitas yang cukup besar dalam risiko outcome dan mortalitas. Major Adverse Cardiovascular Events (MACE) adalah hasil akhir SKA yang didefinisikan sebagai aritmia, syok kardiogenik, gagal jantung, dan kematian. Troponin adalah protein spesifik yang berasal dari otot jantung, di mana fungsinya adalah regulasi kontraksi otot jantung. Kejadian MACE sering ditemukan pada pasien SKA meskipun pasien telah menjalani perawatan intensif. Dengan demikian, dibutuhkan prediksi awal yang besar untuk mengetahui risiko MACE pada penderita SKA, dalam hal ini berupa troponin. Penelitian ini bertujuan untuk mengetahui kadar troponin yang meningkat, sehingga dapat lebih berhati-hati mencegah kejadian MACE pada pasien SKA. Cross-sectional pada pasien SKA yang dirawat di RSI Jemursari Surabaya pada bulan Januari 2014-Desember 2016. Pengambilan sampel dengan teknik consecutive sampling, sebanyak 68 orang. Data dianalisis dengan uji chi-square. Penderita laki-laki lebih banyak dibandingkan dengan penderita perempuan. Kelompok usia terbanyak yang menderita SKA adalah 56-65 tahun, dengan rentang usia 35-85 dan rerata usia 59, 45 $\pm 11,447$ tahun. Hasil penelitian ini menunjukkan bahwa terdapat korelasi antara peningkatan troponin dengan kejadian Major Adverse Cardiovascular Events (MACE) pada pasien sindrom koroner akut dan nilai signifikansi $\mathrm{p}<0,002$. Hasil Odss Ratio (OR) pada pasien SKA dengan peningkatan troponin sebesar 6,5 (IK 95\% 2,112-20,282) $\mathrm{p}<0,002$. Ada korelasi antara peningkatan kadar troponin dengan kejadian Major Adverse Cardiovascular Events (MACE) pada pasien dengan sindrom koroner akut.
\end{abstract}

Kata kunci: troponin, major adverse cardiovascular events (MACE), sindrom koroner akut (SKA)

\begin{abstract}
Acute Coronary Syndrome (ACS) has considerable variability in outcome and mortality risk. Major Adverse Cardiovascular Events (MACE) is outcome of ACS that defined as arrhythmia, cardiogenic shock, heart failure, and death. Troponin is a specific protein that comes from the heart muscle, where its function is to regulation of heart muscle contraction. The incidence of MACE was often found in patients with ACS even though the patient has been in intensive care. Thus it takes a large initial prediction to determine the risk of MACE in patients with ACS, in this case in the form of troponin. This study aims to determine the increased troponin levels, so as to be more careful to prevent the incidence of MACE in patients with ACS. Retrospective with cross-sectional study in ACS patients treated at RSI Jemursari Surabaya in January 2014 - December 2016. Sampling with consecutive sampling technique, as many as 68 people. Data were analyzed by chi-square test. Male patients are more than female patients. The largest age group suffering from ACS is 5665 years, with age range 35-85 and mean age 59, $45 \pm 11,447$ year. The results of this study to show that there is a correlation between troponin increase with incidence of Major Adverse Cardiovascular Events (MACE) in patients with acute coronary syndromes with a significance value of $p<0.002$. Results of Odss Ratio (OR) in patients with SKA with troponin increase of 6.5 (95\% IK 2.11220.228) $\mathrm{p}<0.002$. There is a correlation between elevated levels of troponin with the incidence of Major Adverse Cardiovascular Events (MACE) in patients with acute coronary syndromes.
\end{abstract}

Keywords: troponin, major adverse cardiovascular events (MACE), acute coronary syndrome (ACS) 


\section{PENDAHULUAN}

Penyakit kardio vaskuler merupakan penyebab utama kematian di dunia. Pada tahun 2012, tercatat sebanyak 17,5 juta jiwa dari total 56 juta kasus kematian di dunia disebabkan oleh penyakit kardiovaskuler. Bahkan, WHO memprediksi akan terjadi peningkatan kematian akibat penyakit kardiovaskular dari 17,5 juta jiwa menjadi 23,4 juta jiwa pada tahun $2030^{1}$. Prevalensi penyakit kardiovaskuler di Indonesia sebanyak 7,2\% dengan angka kematian sebesar 5.1\% pada riset kesehatan dasar (riskesdas) tahun $2013^{2}$. Sindrom koroner akut (SKA) merupakan kondisi mengancam nyawa yang bisa terjadi setiap saat pada pasien dengan penyakit jantung koroner. SKA terdiri dari angina pektoris tidak stabil (APTS), infark miokard tanpa ST elevasi (non-ST elevation myocardial infarction/NSTEMI) dan infark miokard dengan ST elevasi (ST elevation myocardial infarction/STEMI), di mana bentuk dari SKA tersebut bergantung kepada derajat oklusiarteri koroner dan hubungannya dengan kejadian iske$\mathrm{mia}^{3}$.

\section{Major adverse cardiovascular event (MACE)} merupakan suatu kejadian komplikasi kardiovaskuler selama fase perawatan, meliputi di antaranya kejadian gagal jantung, syok kardiogenik, aritmia, dan kematian ${ }^{4}$. Pada gobal registry acute coronary events (GRACE), kejadian MACE selama perawatan di rumah sakit sebesar $4,6 \% 0^{5}$.

Troponin merupakan protein spesifik yang berasal dari otot jantung, di mana fungsinya adalah untuk regulasi kontraksi otot jantung ${ }^{6}$. Kejadian MACE masih sering dijumpai pada pasien SKA walaupun pasien tersebut telah mendapatkan perawatan intensif. Dengan demikian dibutuhkan suatu prediksi awal untuk mengetahui besar risiko terjadinya MACE pada pasien SKA, dalam hal ini adalah protein jantung berupa Troponin. Oleh karena itu, peneliti tertarik untuk mengetahui hubungan antara kadar Troponin dengan kejadian major adverse cardiovascular events pada pasien sindrom koroner akut di RSI Jemursari Surabaya dan diharapkan dengan mengetahui peningkatan kadar Troponin dapat lebih berhati-hati untuk mencegah kejadian MACE pada pasien SKA.

\section{METODE PENELITIAN}

Pada penelitian ini menggunakan metode cross-sectional, dengan pengambilan data sekunder yang bersumber dari rekam medis yang bersifat retrospektif. Pengambilan sampel dengan teknik consecutive sampling, sebesar 68 orang. Poulasi pada penelitian adalah pasien sindrom koroner akut yang dirawat di RSI Jemursari Surabaya pada Januari 2014-Desember 2016. Dengan kriteria inklusif yaitu data dari pasien dengan sindrom koroner akut yang dirawat di RSI Jemursari Surabaya dari Januari 2014-Desember 2016; kriteria eksklusi, yaitu chronic kidney disease (CKD), sepsis, emboli paru, data rekam medis yang tidak lengkap. Penelitian ini dilaksanakan pada April-Mei tahun 2017. Kemudian data yang diperoleh diolah dengan menggunakan program SPSS versi 22.0 (IBM Corporation 1989, 2013) dan dalam menguji hipotesis digunakan uji Chi-Square.

\section{HASIL DAN PEMBAHASAN}

\section{Hasil Penelitian}

Jumlah subjek penelitian ini adalah 68 orang dengan jumlah laki-laki sebesar 52 orang $(76,5 \%)$ dan perempuan 16 orang $(23,5 \%)$. Pada usia 35-45 tahun sebanyak 9 orang $(13,2 \%)$, 46-55 sebanyak 15 orang (22\%), 56-65 tahun sebanyak 22 orang (32,3\%), 66-75 sebanyak 16 orang (23,5\%), 76-85 tahun sebanyak 6 orang (9\%), dengan nilai rerata 59,45 $\pm 11,447$ dan 
Median/nilai tengah 60,50. Pada frekuensi kadar Troponin yang meningkat sebanyak 43 orang $(63,2 \%)$ dan yang normal sebanyak 25 orang $(36,8 \%)$, dari seluruh data penelitian, jumlah pasien yang mengalami MACE sebanyak 47 orang (69\%) dan yang tidak mengalami MACE sebanyak 21 orang $(30,1 \%)$ dengan proporsi MACE terbanyak adalah gagal jantung sebanyak 24 orang (51\%). Jenis SKA terbanyak adalah NSTEMI sebanyak 28 orang (41\%) (Tabel 1).

Tabel 1 Hasil Penelitian

\begin{tabular}{|l|l|l|}
\hline \multicolumn{1}{|c|}{ Karakteristik } & Frekuensi & $\begin{array}{l}\text { Persentase } \\
\%\end{array}$ \\
\hline $\begin{array}{l}\text { Jenis Kelamin: } \\
\text { Laki-laki } \\
\text { Perempuan }\end{array}$ & 52 & 76,5 \\
\hline Usia: & 16 & 23,5 \\
$35-45$ & 9 & \\
$46-55$ & 15 & 13,2 \\
$56-65$ & 22 & 22 \\
$66-75$ & 16 & 23,3 \\
$76-85$ & 6 & 9 \\
Mean: $59,45 \pm 11,447 ;$ & & \\
Median: 60,50 & & \\
\hline Troponin: & & \\
Meningkat & 43 & 63.2 \\
Normal & 25 & 36.8 \\
\hline Jenis SKA**: & & \\
UA** & 19 & 28 \\
NSTEMI** & 28 & 41 \\
STEMI** & 21 & 30,1 \\
\hline MACE: & & \\
YA: & 47 & 69 \\
- Gagal Jantung & 24 & 51 \\
- Syok Kardiogenik & 7 & 15 \\
- Aritmia & 12 & 25,5 \\
- Kematian & 4 & 8,5 \\
TIDAK & 21 & 30,1 \\
\hline
\end{tabular}

*SKA: Sindrom Koroner Akut

*UA: Unstable Angina;

**NSTEMI: Non-ST Elevation Myocardial Infarction

**STEMI: ST Elevation Myocardial Infarction

Berdasarkan hasil penelitian, hubungan kadar troponin dengan kejadian MACE dapat dilihat bahwa dari 47 pasien yang terkena MACE,
36 orang $(76,6 \%)$ dengan kadar Troponin yang meningkat dan 11 orang $(23,4 \%)$ dengan kadar Troponin yang normal. Pada uji kemaknaan dengan menggunakan Chi-square didapatkan nilai $P<0,002$ yang berarti terdapat hubungan yang signifikan antara kadar Troponindengan kejadian MACE namun nilai OR yang didapat yaitu 6,545 (IK 95\% 2,112-20,282) hal ini menunjukkan bahwa odds ratio seorang pasien untuk terkena MACE dengan kadar Troponin meningkat adalah 6,5 kali dari pasien dengan kadar Troponin yang normal (Tabel 2).

Tabel 2 Analisis Bivariat

\begin{tabular}{|c|c|c|c|c|c|c|c|}
\hline & & $\begin{array}{c}\text { MACE } \\
\text { Ya }\end{array}$ & & Tidak & & \multirow{2}{*}{ P } & OR (IK 95\%) \\
\cline { 3 - 6 } & $\mathbf{n}$ & $\%$ & $\mathbf{n}$ & $\%$ & & \\
\hline TROPONIN & Meningkat & 36 & $\begin{array}{r}76, \\
6\end{array}$ & 7 & 33,3 & $\begin{array}{c}< \\
0,002\end{array}$ & $6.545(2,112-20,282)$ \\
\hline
\end{tabular}

\section{Pembahasan}

Pada pasien sindrom koroner akut yang berjenis kelamin laki-laki adalah 52 orang $(76,5 \%)$, sedangkan perempuan adalah 16 orang $(23,5 \%)$. Hasil ini sesuai dengan penelitian yang dilakukan oleh Torryet all yang menunjukkan bahwa penderita laki-laki (32 orang) lebih banyak dibandingkan perempuan (12 orang) pada tahun 2013 di bagian/SMF Ilmu Penyakit Dalam RSU Bethesda Tomohon. Kesamaan ini terjadi karena lakilaki merupakan faktor risiko terjadinya sindrom koroner akut ${ }^{7}$.

Pada penelitian ini terdapat 9 orang $(13,2 \%)$ penderita termasuk dalam kelompok usia 3545 tahun, 15 orang (22\%) penderita termasuk dalam kelompok usia 46-55 tahun, 22 orang $(32,3 \%)$ termasuk dalam kelompok usia 56-65 tahun, 16 orang $(23,5 \%)$ termasuk dalam kelompok usia 66-75 tahun, 6 orang (9\%) penderita termasuk dalam kelompok usia 76-85 tahun, di mana usia yang paling muda pada pasien SKA 
tersebut adalah 35 tahun dan usia paling tua adalah 83 tahun. Hal ini sesuai dengan penelitian yang dilakukan oleh Ramadhani et al. bahwa kelompok usia 41-60 tahun merupakan kelompok usia penderita terbanyak. Hal ini sesuai dengan teori mengenai usia.

Pada pasien sindrom koroner akut yang berjenis kelamin laki-laki adalah 52 orang $(76,5 \%)$, sedangkan perempuan adalah 16 orang $(23,5 \%)$. Hasil ini sesuai dengan penelitian yang dilakukan oleh Torryet et al. yang menunjukkan bahwa penderita laki-laki (32 orang) lebih banyak dibandingkan perempuan (12 orang) pada tahun 2013 di bagian /SMF Ilmu Penyakit Dalam RSU Bethesda Tomohon. Kesamaan ini terjadi karena laki-laki merupakan faktor risiko terjadinya sindrom koroner akut ${ }^{7}$.

Pada penelitian ini terdapat 9 orang $(13,2 \%)$ penderita termasuk dalam kelompok usia 3545 tahun, 15 orang (22\%) penderita termasuk dalam kelompok usia 46-55 tahun, 22 orang $(32,3 \%)$ termasuk dalam kelompok usia 56-65 tahun, 16 orang $(23,5 \%)$ termasuk dalam kelompok usia 66-75 tahun, 6 orang (9\%) penderita termasuk dalam kelompok usia 76-85 tahun, di mana usia yang paling muda pada pasien SKA tersebut adalah 35 tahun dan usia paling tua adalah 83 tahun. Hal ini sesuai dengan penelitian yang dilakukan oleh Ramadhaniet et al., bahwa kelompok usia 41-60 tahun merupakan kelompok usia penderita terbanyak. Hal ini sesuai dengan teori mengenai usia yang termasuk dalam faktor risiko terkena sindrom koroner adalah $>45$ tahun laki-laki dan $>$ dari 55 tahun untuk perempuan ${ }^{8}$.

Pasien SKA dengan troponin normal sebanyak 25 orang $(36,8 \%)$ dan troponin meningkat sebanyak 43 orang $(63,2 \%)$, di mana peningkatan hasil pemeriksaan troponin dapat mencapai $60 \%$. Pasien SKA yang mengalami MACE sebanyak 47 orang (69\%) dan yang tidak mengalami MACE sebanyak 21 orang (30,1\%). Pada 47 orang (69\%) yang mengalami MACE, dengan troponin normal sebanyak 11 orang $(23,4 \%)$ dan troponin yang meningkat sebanyak 36 orang $(76,6 \%)$. Berdasarkan uji statistik deskriptif dengan uji Chi-square ini didapatkan $p<0,002$, dengan nilai $\alpha<0,05$, pada peningkatan Troponin terhadap terjadinya MACE, hal ini menunjukkan bahwa adanya hubungan peningkatan kadar Troponin dengan MACE. Selain itu, seorang pasien yang mengalami SKA dengan peningkatan kadar Troponin memiliki risiko untuk terjadinya MACE yaitu sebesar 6,5 (IK 95\% 2,112-20,282) kali lebih besar dari pada pasien yang mengalami SKA dengan kadar Troponin yang normal.

Hasil penelitian ini sesuai dengan penelitian Ang, dkk. Pada penelitian tersebut didapatkan hasil bahwa pasien dengan peningkatan Troponin memiliki risiko terjadinya MACE 6 kali lebih besar dibandingkan dengan pasien yang memiliki kadar Troponin yang normal dengan unadjusted RR 6,11 (IK 95\%, 2,98-12,50) ${ }^{9}$. Selain itu, pada penelitian Sanchiset et al., menjelaskan bahwa troponin merupakan factor prediktif untuk menilai dampak pada manajemen dan hasil terapi pasien SKA. Pada pasien yang mengalami SKA dengan Troponin yang tinggi meningkat akan risiko rawat inap 1,35 kali yang lebih lama dibandingkan dengan pasien yang memiliki kadar troponin normal $(\mathrm{OR}=1,35$, $95 \%$ CI 1,07 sampai $1,71, \mathrm{p}=0,02)^{10}$

\section{SIMPULAN DAN SARAN}

\section{Simpulan}

Pada pasien SKA (sindrom koroner akut) dengan faktor risiko laki-laki dari 68 sampel didapatkan 52 orang (76,5\%), sedangkan nilai rerata usia 59, $45 \pm 11,447$ dan median 60,50, 
Elsa Kusumawati, Abraham Ahmad A.F., Reza Hery M.P., Hubungan antara Kadar Troponin dengan Kejadian Major Adverse Cardiovascular Events pada Pasien Sindrom Koroner Akut di RSI Jemursari Surabaya

dengan jumlah terbanyak kelompok usia 56-65 tahun, di mana didapatkan usia yang paling muda yaitu 35 tahun dan usia yang paling tua yaitu 83 tahun.

Proporsi MACE (Major Adverse Cardiovascular Events) pada pasien SKA di Rumah Sakit Islam Jemursari Surabaya pada Januari 2014Desember 2016 adalah sebesar 69,1\%, dengan jenis MACE terbanyak yaitu gagal jantung sebesar $51 \%$.

Peningkatan kadar Troponin admisi sebagai faktor predictor terjadinya MACE pada pasien SKA dengan OR 6,5 (IK 95\% 2,112-20,282), $\mathrm{P}<0,002$, yang menunjukkan bahwa pasien SKA dengan peningkatan kadar troponin dapat mengalami MACE sebesar 6,5 kali dari pasien dengan kadar troponin yang normal. Sehingga dengan mengetahui kadar troponin pada pasien SKA dapat lebih berhati-hati untuk mencegah kejadian MACE pada pasien SKA.

\section{DAFTAR RUJUKAN}

Ang DSC, Michelle PCK, Ellie D, et al. 2012. The Prognostic Value Of High Sensitivity Troponin $T 7$ Weeks An Acute Coronary Syndrome. Heart; 98:1160-1165.

Granger C.B., Robert J.G., Omar D., et al. 2003. Predictors of Hospital Mortality in the Global Registry of Acute Coronary Events. Arch Interns Med; 163:2345-53.

Leonard S. Lilly. 2011. Pathophysiology of Heart Disease A Collaborative Project of Medical Students and Faculty Fifth Edition. Lippicott Williams \& Wilkins.

Martalena, Dewi, Nasution A. Sally., Purnamasari, Dyah, et al. 2013. Pengaruh Hiper- glikemia Admisi Terhadap Major Adverse Cardiac Events Selama Perawatan pada Pasien Sindrom Koroner Akut di ICCU RSCM. Jakarta. Rumah Sakit Cipto Mangunkusumo, Jakarta: Departemen Ilmu Penyakit Dalam Fakultas Kedokteran Universitas Indonesia.

Mihardja L.K., Delima, Soetiarto F., dkk. 2013. Penyakit Tidak Menular. In: Kementerian Kesehatan Republik Indonesia, Penyunting. Riset Kesehatan Dasar. Jakarta: Badan Penelitian dan Pengembangan Kesehatan Kementerian Republik Indonesia, p. 8399 SKRT. DepKes RI. Survei Kesehatan Rumah tangga. 1995.

Ramadhani, BYS., Rotty, LWA., Wantania, F. 2013. Gambaran Hematolohi pada Pasien Sindrom Koroner Akut yang Dirawat di BLU RSUP Prof. Dr. R. D. Kandou Manado tabun 2010. Manado; 1:12-6.

Sanchis, J. et al. 2014. 'High-Sensitivity versus Conventional Troponin for Management and Prognosis Assessment of Patients with Acute Chest Pain', Heart. doi: 10.1136/ heartjnl-2013-305440.

Sood, Ramnik. 2006. Textbook of Medical Laboratory Technology. Jaypee Brothers.

Tedros, Adhanom, G., Svetlana, Akselrod., Peter, Salama., et al. World Health Organization, WHO. 2016. Cardiovascular Diseases. Available from :http://www.who.int/ mediacentre/fs317/en/. Diakses 22 Oktober 2016.

Torry, S.R.V, Panda, A.L. and Ongkowijaya, J. 2013. 'Gamabaran Faktor Risiko Penderita Sindrom Koroner Akut', universitas Sam Ratulangi, pp. 1-8. 
Medical and Health Science Journal, Vol. 2, No. 1, February 2018 